\title{
Excessive iodine intake, water chemicals and endemic goitre in a Sudanese coastal area
}

\author{
Abdel Monim MH Medani ${ }^{1, *}, t$, Abdelsalam A Elnour ${ }^{2}$ and Amal M Saeed ${ }^{3}$ \\ ${ }^{1}$ Sudan Atomic Energy Commission, Khartoum, Sudan: ${ }^{2}$ College of Medicine, University of Dammam, \\ Dammam, Saudi Arabia: ${ }^{3}$ Faculty of Medicine, University of Khartoum, Khartoum, Sudan
}

Submitted 22 November 2011: Final revision received 12 July 2012: Accepted 24 August 2012: First published online 16 November 2012

\begin{abstract}
Objective: To study the associations between intakes of iodine and water chemicals and the thyroid gland status of schoolchildren living in the coastal city of Port Sudan.

Design: In our previous nationwide study on goitre, it was observed that the prevalence of goitre was high in Port Sudan city despite high urinary iodine excretion. A cross-sectional study including schoolchildren aged 6-12 years was designed. Measurements determined the prevalence of goitre, urinary iodine concentration and thiocyanate secretion in casual urine samples, serum levels of thyroxine, triiodothyronine, thyroid-stimulating hormone and thyroglobulin, as well as the levels of $\mathrm{Cl}^{-}, \mathrm{F}, \mathrm{Ca}^{2+}, \mathrm{Mg}^{2+}$ and total hardness of drinking water. Subjects: Schoolchildren ( $n$ 654) aged 6-12 years.

Setting: Port Sudan city is located at the western bank of the Red Sea. The city is surrounded by a mountainous area known as the Red Sea Hills. It is the main sea port in the Sudan, inhabited by ethnically and socio-economically heterogeneous populations.

Results: The prevalence of goitre in Port Sudan was $34.86 \%$ while the median urinary iodine concentration was $46.4 \mu \mathrm{g} / \mathrm{dl}$. Out of thirty-one pupils from Port Sudan, twenty-four $(77 \cdot 42 \%)$ were found to have urinary iodine concentration greater than $30 \mu \mathrm{g} / \mathrm{dl}$ and twelve $(38.71 \%)$ had different degrees of biochemical hypothyroidism. Excessive concentrations of $\mathrm{Cl}^{-}, \mathrm{Ca}^{2+}, \mathrm{Mg}^{2+}$ and water hardness $(369 \cdot 2,116 \cdot 48,60 \cdot 21$ and $539 \cdot 0 \mathrm{mg} / 1$, respectively) were detected in drinking water samples collected from Port Sudan that exceeded levels permitted by the WHO. Conclusions: The coastal city of Port Sudan is a goitre-endemic area. In contrast to other Sudanese cities in which endemic goitre is related to iodine deficiency, goitre in Port Sudan is associated with iodine excess. Water chemicals seemed to have no effects on thyroid status.
\end{abstract}

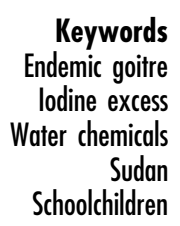

Iodine is a requirement for, as well as a regulator of, the thyroid gland ${ }^{(1)}$. While iodine deficiency may impair thyroid function, iodine excess has been shown to inhibit thyroid hormone synthesis and release through the Wolff-Chaikoff effect ${ }^{(2,3)}$. Thus both iodine deficiency and iodine excess might result in thyroid dysfunction via a U-shaped relationship ${ }^{(4)}$. In addition to direct impairment of thyroid function, excessive iodine intake is also believed to induce some autoimmune diseases ${ }^{(3)}$. Excess iodine may exist naturally such as that reported in coastal Hokkaido in Japan. In this coastal area, goitre was found to be endemic among Japanese children due to consumption of seaweed $^{(5)}$. An association between excess iodine intake, increased serum thyroid-stimulating hormone (TSH) and

$\dagger$ Present address: Al-Farabi College, Haramain Road, PO Box 21512, Jeddah 45017, Kingdom of Saudi Arabia.

*Corresponding author: Email abdelmonimh@gmail.com

thyroid volume was detected in China where drinking water is rich in iodine ${ }^{(6)}$. Excess iodine consumption can also result from additional supplies of iodine to the daily intake in different forms. Endemic goitre was associated with excessive iodine given to refugees in four African countries in the form of fortified food ${ }^{(7)}$. Distribution of iodized salt poorly monitored for the iodine concentration resulted in excess iodine intake in Iceland $^{(8)}$. In addition to alteration in iodine intake, other factors have been suggested to be causative agents or contributors to the development of endemic goitre. Among these are genetic or racial factors ${ }^{(9)}$, dietary goitrogens and high concentrations of some minerals in drinking water ${ }^{(10)}$. Water has a significant role in body homeostasis and metabolism because of its large consumption and high content of trace elements. It has been reported that chlorine and some other chemicals can form different products when they react with organic matter in 
the upper gastrointestinal tract. These products exert significant antithyroidal effects ${ }^{(11,12)}$. Several environmental chemicals have structural similarities to the thyroid hormones thyroxine $\left(\mathrm{T}_{4}\right)$ and triiodothyronine $\left(\mathrm{T}_{3}\right)$. These similarities may lead to interference with thyroid homeostasis through many mechanisms of action at different levels of metabolism of thyroid hormones ${ }^{(10)}$. This may lead to insufficient production of hormones by the thyroid gland. Calcium was found to be goitrogenic in rats on a low-iodine diet ${ }^{(13)}$.

Excess fluoride was reported as a major cause of endemic goitre in the presence of iodine sufficiency in different parts of South Africa ${ }^{(14,15)}$. A similar relationship between excess fluoride exposure and goitre has been detected in England as well as in the Punjab region of India $^{(16)}$. A close relationship between goitre prevalence and the fluoride content and hardness of water was reported by Day and Powell-Jackson ${ }^{(17)}$. They reported that the prevalence of goitre in some Himalayan villages was attributable to the content of chemicals in water rather than to differences in iodine intake.

The Sudan is located in the middle of a goitre-endemic area. This area includes Algeria, Burundi, Chad, Central African Republic, Congo, Egypt, Eritrea, Ethiopia, Kenya, Mali, Niger, Rwanda, Tunisia and Uganda ${ }^{(18)}$. The endemicity of goitre varies from $12 \%$ in Congo to as high as $65 \%$ in Algeria.

The Sudan is like other goitre-endemic areas in which iodine deficiency has been implicated as the main aetiological factor ${ }^{(1)}$. The contribution of other factors, like consumption of pearl millet ${ }^{(19,20)}$, protein-energy malnutrition and vitamin A deficiency ${ }^{(21)}$, was noted. In a recent goitre survey, we reported a high prevalence of goitre in eleven Sudanese cities, representing nine states. Goitre prevalence ranged from 12 to $78 \%{ }^{(22)}$. Iodine deficiency was widespread in the ten non-coastal cities, with median urinary iodine concentration (UIC) ranging from $2 \cdot 7$ to $9 \cdot 4 \mu \mathrm{g} / \mathrm{dl}$. The coastal city of Port Sudan, on the other hand, had an exceptionally high median UIC of $46.4 \mu \mathrm{g} / \mathrm{dl}$. The goitre prevalence in Port Sudan was $34.9 \%$ while the combined prevalence in the other cities was $39 \cdot 3 \%$. Iodine deficiency could explain the high prevalence of endemic goitre in these ten cities. The intention in the present study was to examine possible associations between UIC, water chemicals and thyroid status in the coastal city of Port Sudan.

\section{Methods}

A national cross-sectional study for determination of the status of iodine-deficiency disorders in the Sudan was conducted from June to November $2006^{(22)}$. The study included schoolchildren aged 6-12 years randomly selected from thirty-three preliminary schools in eleven cities. Each city was first divided into three sectors and one school was randomly selected from each sector. Sample sizes were calculated using a rapid, populationbased, multistage random sampling technique ${ }^{(23)}$. In each school, the first, third and fifth year classrooms were selected to participate in the study.

The total number of schoolchildren enrolled in the study was 6038. Out of those, 654 were from Port Sudan city which is the main sea port of the Sudan, connected to Khartoum via a $1200 \mathrm{~km}$ highway and recently with another $800 \mathrm{~km}$ road. The city is located in an arid area with very saline water. Food and drinking water are imported into Port Sudan from different areas around.

\section{Measurements}

Goitre

Goitre was assessed by the same observer for the pupils (in the selected classrooms) who attended school on the day of the survey. Goitre size was graded according to the criteria recommended by the WHO, UNICEF and the International Council for the Control of Iodine Deficiency Disorders (grade 0, no goitre; grade 1, thyroid palpable but not visible; and grade 2 , thyroid visible with neck in normal position) ${ }^{(24)}$. The combined prevalence of grade 1 and 2 provided the total prevalence of goitre in the study population.

\section{Laboratory study}

Four children from each classroom were selected to participate in the laboratory study using a systematic random sampling technique. The number of pupils in the class was divided by four to determine the sample interval $(X)$ in each class. Using the simple random technique a random digit was selected within the sample interval as starting point. $X$ was then added to the number of the first child to select the second in the sample.

Blood and urine samples were collected from thirty-one pupils from Port Sudan and from 329 pupils from the other Sudanese cities. Pupils were chosen irrespective of gender or the results of thyroid gland palpation. Serum samples were analysed for $\mathrm{T}_{4}, \mathrm{~T}_{3}$, TSH and thyroglobulin (Tg) using RIA with reagents obtained from the Department of Isotopes of the China Institute for Atomic Energy in Beijing (the multichannel gamma counter for measuring ${ }^{125}$ I was obtained from Stratec Biomedical Systems AG, Birkenfeld, Germany).

Urine samples were used for two purposes: (i) a fresh portion was used to determine the UIC; and (ii) a portion that was kept at $-20^{\circ} \mathrm{C}$ for 5 months was used to measure urinary thiocyanate (USCN). UIC was measured using the modified Sandell-Kothoff reaction ${ }^{(25)}$. USCN excretion was measured by the modified method of Aldridge ${ }^{(26)}$ described by Michajlovskij and Langer ${ }^{(27)}$ (using a photometer from Biosystems SA, Barcelona, Spain).

Blood and urine samples were analysed in the laboratories of the Sudan Atomic Energy Commission (SAEC), Khartoum. 
The present study was approved by the review board of the Sudanese Academy of Sciences, and consent was obtained from local health and education authorities and the Department of School Nutrition of the Ministry of Education. Permission for collecting blood and urine samples was obtained verbally from one of the parents of each pupil through school headmasters and parent councils. Pupils who declined to participate were randomly substituted with other pupils from the same classroom.

The study covered an ethnically and socio-economically heterogeneous population of schoolchildren who varied considerably with respect to their sources of drinking water and staple foods. Comparisons of the thyroid parameters between thirty-one pupils from Port Sudan and 329 from the rest of the Sudan were obtained. In addition to the mentioned parameters, thirty-one drinking water samples were collected from the houses of the participating pupils from Port Sudan. The water samples represented three localities where the schools were situated and selected accordingly.

Water samples were analysed for their concentrations of $\mathrm{Ca}^{2+}, \mathrm{Mg}^{2+}, \mathrm{Cl}^{-}$and $\mathrm{F}^{-}$and total hardness $\left(\mathrm{CaCO}_{3}\right.$ concentration). $\mathrm{Ca}^{2+}$ and $\mathrm{Mg}^{2+}$ in water samples was measured using the EDTA titrimetric method ${ }^{(28)}$, which involves addition of Eriochrome Black or Calmagite dye to an aqueous solution containing $\mathrm{Ca}^{2+}$ and $\mathrm{Mg}^{2+}$ at $\mathrm{pH}$ $10 \cdot 0 \pm 0 \cdot 1$ after addition of EDTA as chelating titrant. $\mathrm{Cl}^{-}$was measured using the argentometric method ${ }^{(28)}$ that depends on the titration of $\mathrm{Cl}^{-}$with $\mathrm{AgNO}_{3}$ using $\mathrm{K}_{2} \mathrm{CrO}_{4}$ for detection of the end point. The reaction took place in a neutral or slightly alkaline medium. $\mathrm{F}^{-}$was measured by the SPADNS colorimetric method ${ }^{(28)}$ using zirconium-dye lake to form the colourless complex anion $\left(\mathrm{ZrF}_{6}\right)^{2-}$. The analysis of water samples took place at the central laboratory belonging to the laboratories department of the Groundwater \& Wadis Directorate in Khartoum (micropipettes (20-100 $\mu$ l) and repeating syringes for measuring specific volumes of serum and urine were from obtained Eppendorf GmbH, Hamburg, Germany).

\section{Statistical analysis}

Statistical analyses were performed using the statistical software package SPSS version $16 \cdot 0$. The central tendency was described by the arithmetic mean of serum and urine levels. Spearman's correlation coefficient was used to explore the relationship between variables $\left(\mathrm{T}_{4}, \mathrm{~T}_{3}, \mathrm{TSH}, \mathrm{Tg}\right.$, UIC, USCN and water chemical components). One-way ANOVA was used to explore differences in mean serum $\mathrm{T}_{4}$, $\mathrm{T}_{3}$, TSH, Tg, UIC and USCN levels between Port Sudan and the other Sudanese cities. The procedure of least significant difference was applied to look for differences among pairs of means. Significance was set at $P<0 \cdot 05$.

\section{Results}

Table 1 presents the mean UIC, USCN and thyroid parameters (serum levels of $\mathrm{T}_{4}, \mathrm{~T}_{3}, \mathrm{TSH}$ and $\mathrm{Tg}$ ) of thirty-one children from Port Sudan city in comparison with the combined means of 329 children from the other ten Sudanese cities. The mean UIC in Port Sudan was about five times the combined mean UIC of the other Sudanese cities $(P=0 \cdot 001)$. Compared with children from the other Sudanese cities, the children in Port Sudan had significantly lower serum $\mathrm{T}_{4}$ and $\mathrm{T}_{3}$ levels (both $P=0 \cdot 001$ ) and significantly higher serum TSH level $(P=0 \cdot 008)$. The mean serum level of $\mathrm{Tg}$ of the children in Port Sudan was higher than the combined mean of the children in the other cities; however, the difference between the two means was noticeable but statistically insignificant $(P=0 \cdot 052)$. The mean USCN in the Port Sudan children was significantly lower than the combined mean of the children in other cities $(P=0 \cdot 001)$.

Furthermore, the UIC of children in Port Sudan ranged from 10.9 to $73.6 \mu \mathrm{g} / \mathrm{dl}$. Out of thirty-one pupils in this

Table 1 Clinical indicators of thyroid function and iodine status in schoolchildren aged 6-12 years from Port Sudan city compared with other Sudanese cities, June-November 2006

\begin{tabular}{|c|c|c|c|c|c|c|c|}
\hline & \multirow[b]{2}{*}{ Group } & \multirow[b]{2}{*}{$n$} & \multirow[b]{2}{*}{ Mean } & \multirow[b]{2}{*}{ SD } & \multirow[b]{2}{*}{$P$ value } & \multicolumn{2}{|c|}{$95 \% \mathrm{Cl}$} \\
\hline & & & & & & Lower & Upper \\
\hline \multirow[t]{2}{*}{$\mathrm{T}_{4}(\mathrm{nmol} / \mathrm{l})$} & Sudanese cities & 329 & $105 \cdot 17$ & $27 \cdot 42$ & 0.001 & $12 \cdot 45$ & $32 \cdot 74$ \\
\hline & Port Sudan & 31 & $82 \cdot 58$ & $27 \cdot 93$ & & & \\
\hline \multirow[t]{2}{*}{$\mathrm{T}_{3}(\mathrm{nmol} / \mathrm{l})$} & Sudanese cities & 329 & $1 \cdot 97$ & 0.51 & 0.001 & 0.24 & 0.62 \\
\hline & Port Sudan & 31 & 1.54 & 0.48 & & & \\
\hline \multirow[t]{2}{*}{ TSH (mIU/l) } & Sudanese cities & 329 & $2 \cdot 11$ & $1 \cdot 28$ & 0.008 & $-2 \cdot 74$ & -0.46 \\
\hline & Port Sudan & 31 & $3 \cdot 71$ & $3 \cdot 10$ & & & \\
\hline \multirow[t]{2}{*}{$\mathrm{Tg}(\mathrm{ng} / \mathrm{ml})$} & Sudanese cities & 329 & $37 \cdot 22$ & $21 \cdot 86$ & 0.052 & $-16 \cdot 93$ & -0.67 \\
\hline & Port Sudan & 31 & $46 \cdot 02$ & 23.45 & & & \\
\hline \multirow[t]{2}{*}{ UIC $(\mu \mathrm{g} / \mathrm{dl})$} & Sudanese cities & 329 & $7 \cdot 01$ & $5 \cdot 17$ & 0.001 & $-45 \cdot 20$ & $-31 \cdot 36$ \\
\hline & Port Sudan & 31 & $45 \cdot 29$ & $18 \cdot 83$ & & & \\
\hline \multirow[t]{2}{*}{ USCN (mg/l) } & Sudanese cities & 329 & $0 \cdot 40$ & $0 \cdot 17$ & 0.001 & 0.06 & $0 \cdot 15$ \\
\hline & Port Sudan & 31 & $0 \cdot 29$ & 0.11 & & & \\
\hline
\end{tabular}

$\mathrm{T}_{4}$, thyroxine; $\mathrm{T}_{3}$, triiodothyronine; TSH, thyroid-stimulating hormone; Tg, thyroglobulin; UIC, urinary iodine concentration; USCN, urinary thiocyanate. Normal total serum levels of $\mathrm{T}_{4}, \mathrm{~T}_{3}, \mathrm{TSH}$ and $\mathrm{Tg}$ according to the Sudan Atomic Energy Commission are as follows: $\mathrm{T}_{4}, 60-165 \mathrm{nmol} / \mathrm{l} ; \mathrm{T}_{3}, 0 \cdot 8-3 \cdot 0 \mathrm{nmol} / \mathrm{l}$; $\mathrm{TSH}, 0 \cdot 7-5 \cdot 0 \mathrm{mIU} / \mathrm{l} ; \mathrm{Tg}, 4 \cdot 1-24 \cdot 0 \mathrm{ng} / \mathrm{ml}$. 


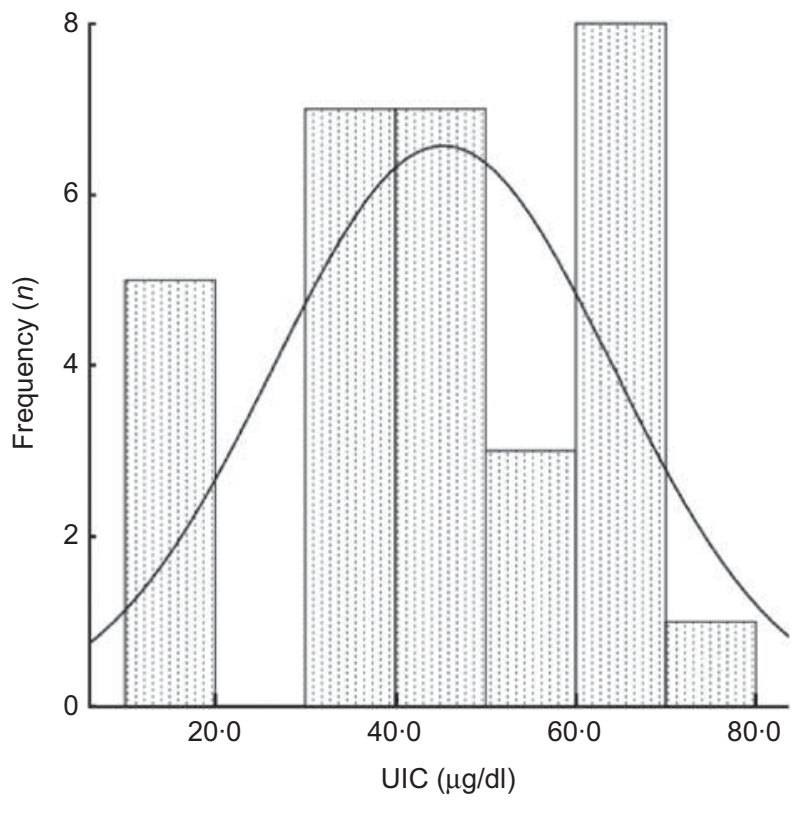

Fig. 1 Distribution of urinary iodine concentration (UIC) among thirty-one schoolchildren aged 6-12 years from Port Sudan city, June-November 2006 (mean UIC = 45.29 (SD 18.82) $\mu \mathrm{g} / \mathrm{dl})$

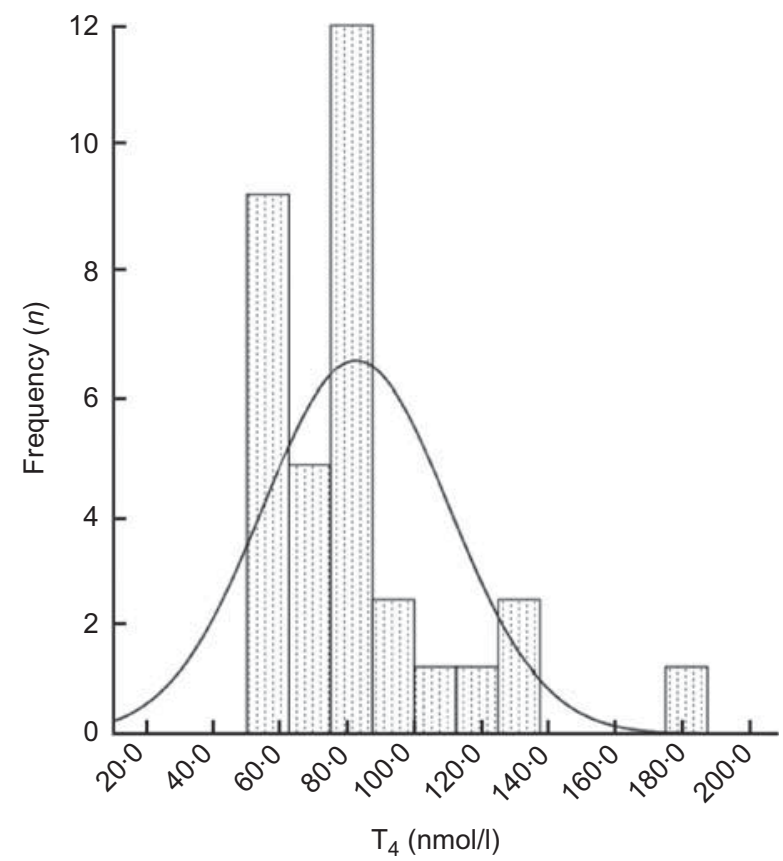

Fig. 2 Distribution of serum thyroxine $\left(\mathrm{T}_{4}\right)$ levels among thirtyone schoolchildren aged 6-12 years from Port Sudan city, June-November 2006 (mean $\mathrm{T}_{4}=82.58$ (SD 27.93) nmol/l)

city, twenty-four $(77 \cdot 42 \%)$ were found to have excessive UIC greater than $30 \mu \mathrm{g} / \mathrm{dl}$, the upper limit of normal UIC estimated by the WHO (Fig. 1). Seven children had serum $\mathrm{T}_{4}$ lower than the lowest normal $\mathrm{T}_{4}$ level estimated by the SAEC, which is $60 \mathrm{nmol} / 1$. Only one child had serum $\mathrm{T}_{4}$ above $165 \mathrm{nmol} / \mathrm{l}$, which is the upper normal $\mathrm{T}_{4}$ level

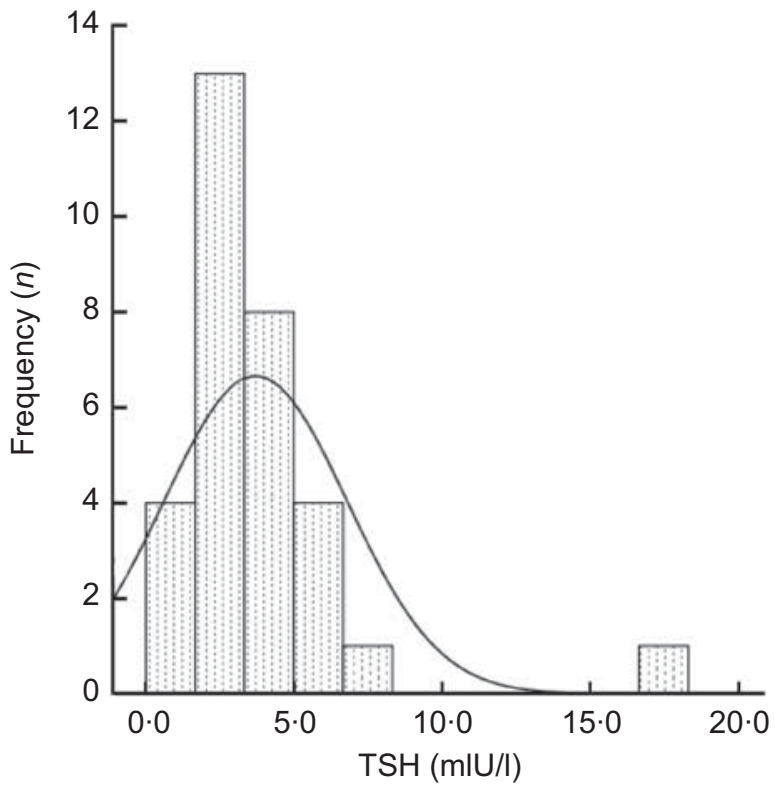

Fig. 3 Distribution of serum thyroid-stimulating hormone (TSH) levels among thirty-one schoolchildren aged 6-12 years from Port Sudan city, June-November 2006 (mean TSH $=3 \cdot 71$ (sD $3 \cdot 10) \mathrm{mlU} / \mathrm{l})$

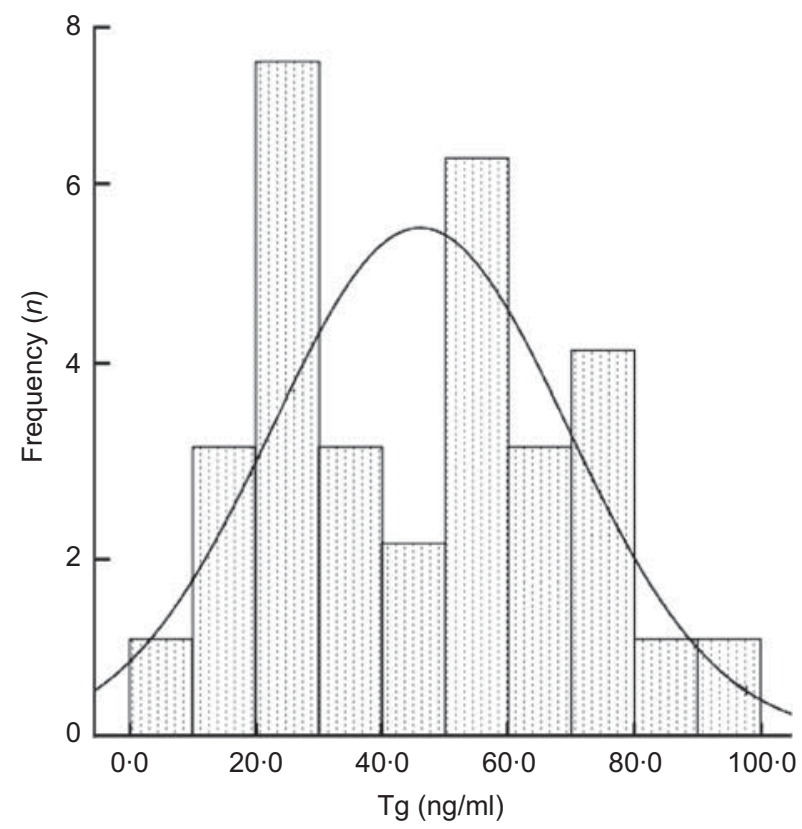

Fig. 4 Distribution of serum thyroglobulin ( $\mathrm{Tg}$ ) levels among thirty-one schoolchildren aged 6-12 years from Port Sudan city, June-November 2006 (mean Tg = 46.02 (sD 23.45) ng/ml)

estimated by the SAEC (Fig. 2). High serum TSH values were detected in another six children that exceeded the SAEC normal value $(0.5-5 \mathrm{mIU} / 1)$, as shown in Fig. 3. Moreover, serum Tg concentration was elevated in twenty-five children $(80 \cdot 65 \%)$ that exceeded the highest normal value $(24 \mathrm{ng} / \mathrm{ml})$ estimated by the SAEC (Fig. 4 ). 
Table 2 Correlation between various clinical indicators of thyroid function, iodine status and water chemicals in a study of thirty-one schoolchildren aged 6-12 years from Port Sudan city, June-November 2006

\begin{tabular}{|c|c|c|c|c|c|c|c|c|c|c|c|c|}
\hline & & $\begin{array}{c}\mathrm{T}_{4} \\
(\mathrm{nmol} / \mathrm{l})\end{array}$ & $\begin{array}{c}\mathrm{T}_{3} \\
(\mathrm{nmol} / \mathrm{l})\end{array}$ & $\begin{array}{l}\text { TSH } \\
(\mathrm{mlU} / \mathrm{l})\end{array}$ & $\begin{array}{c}\mathrm{Tg} \\
(\mathrm{ng} / \mathrm{ml})\end{array}$ & $\underset{(\mu \mathrm{g} / \mathrm{dl})}{\mathrm{UIC}}$ & $\begin{array}{l}\text { USCN } \\
(\mathrm{mg} / \mathrm{l})\end{array}$ & $\begin{array}{c}\mathrm{Cl}^{-} \\
(\mathrm{mg} / \mathrm{l})\end{array}$ & $\begin{array}{l}\mathrm{Ca}^{2+} \\
(\mathrm{mg} / \mathrm{l})\end{array}$ & $\begin{array}{l}\mathrm{Mg}^{2+} \\
(\mathrm{mg} / \mathrm{l})\end{array}$ & $\begin{array}{c}\mathrm{F}^{-} \\
(\mathrm{mg} / \mathrm{l})\end{array}$ & Hardness \\
\hline \multirow[t]{2}{*}{$\mathrm{T}_{4}(\mathrm{nmol} / \mathrm{l})$} & $r+$ & $1 \cdot 000$ & $0 \cdot 203$ & $0 \cdot 218$ & $0 \cdot 277$ & $-0 \cdot 101$ & $0 \cdot 120$ & -0.043 & $-0 \cdot 157$ & -0.043 & $0 \cdot 157$ & $-0 \cdot 157$ \\
\hline & $P$ value $\neq$ & & 0.273 & 0.238 & $0 \cdot 131$ & 0.589 & 0.520 & $0 \cdot 818$ & 0.398 & 0.818 & 0.398 & 0.398 \\
\hline \multirow{2}{*}{$\mathrm{T}_{3}(\mathrm{nmol} / \mathrm{l})$} & $r$ & - & $1 \cdot 000$ & $0 \cdot 148$ & 0.341 & -0.042 & -0.020 & -0.096 & -0.179 & -0.096 & $0 \cdot 179$ & $-0 \cdot 179$ \\
\hline & $P$ value & - & - & 0.426 & 0.061 & 0.823 & 0.913 & 0.609 & 0.335 & 0.609 & 0.335 & 0.335 \\
\hline \multirow[t]{2}{*}{ TSH (mIU/l) } & $r$ & - & - & $1 \cdot 000$ & $0 \cdot 381^{*}$ & $-0 \cdot 102$ & -0.194 & -0.102 & $-0.506^{*}$ & $-0 \cdot 102$ & $0.506^{*}$ & $-0 \cdot 506^{\star}$ \\
\hline & $P$ value & - & - & - & 0.034 & 0.585 & 0.296 & 0.586 & 0.004 & 0.586 & 0.004 & 0.004 \\
\hline \multirow{2}{*}{$\operatorname{Tg}(\mathrm{ng} / \mathrm{ml})$} & $r$ & - & - & - & $1 \cdot 000$ & -0.020 & 0.042 & $-0 \cdot 208$ & -0.260 & -0.208 & 0.260 & -0.260 \\
\hline & $P$ value & - & - & - & - & 0.915 & 0.823 & 0.262 & $0 \cdot 159$ & 0.262 & 0.159 & 0.159 \\
\hline \multirow[t]{2}{*}{ UIC ( $\mu \mathrm{g} / \mathrm{dl})$} & $r$ & - & - & - & - & 1.000 & 0.326 & $-0.405^{\star}$ & 0.058 & $-0 \cdot 405^{\star}$ & -0.058 & 0.058 \\
\hline & $P$ value & - & - & - & - & - & 0.074 & 0.024 & 0.758 & 0.024 & 0.758 & 0.758 \\
\hline \multirow{2}{*}{ USCN (mg/l) } & $r$ & - & - & - & - & - & $1 \cdot 000$ & -0.021 & 0.061 & -0.021 & -0.061 & 0.061 \\
\hline & $P$ value & - & - & - & - & - & - & 0.910 & $0 \cdot 744$ & 0.910 & 0.744 & 0.744 \\
\hline \multirow[t]{2}{*}{$\mathrm{Cl}^{-}(\mathrm{mg} / \mathrm{l})$} & $r$ & - & - & - & - & - & - & $1 \cdot 000$ & $0 \cdot 312$ & $1 \cdot 000^{*}$ & $-0 \cdot 312$ & 0.312 \\
\hline & $P$ value & - & - & - & - & - & - & - & 0.087 & 0.001 & 0.087 & 0.087 \\
\hline \multirow[t]{2}{*}{$\mathrm{Ca}^{2+}(\mathrm{mg} / \mathrm{l})$} & $r$ & - & - & - & - & - & - & - & $1 \cdot 000$ & 0.312 & $-1 \cdot 000^{\star}$ & $1 \cdot 000^{*}$ \\
\hline & $P$ value & - & - & - & - & - & - & - & - & 0.087 & 0.001 & 0.001 \\
\hline \multirow[t]{2}{*}{$\mathrm{Mg}^{2+}(\mathrm{mg} / \mathrm{l})$} & $r$ & - & - & - & - & - & - & - & - & $1 \cdot 000$ & -0.312 & 0.312 \\
\hline & $P$ value & - & - & - & - & - & - & - & - & - & 0.087 & 0.087 \\
\hline \multirow{2}{*}{$\mathrm{F}^{-}(\mathrm{mg} / \mathrm{l})$} & $r$ & - & - & - & - & - & - & - & - & - & $1 \cdot 000$ & $-1 \cdot 000^{*}$ \\
\hline & $P$ value & - & - & - & - & - & - & - & - & - & - & 0.001 \\
\hline \multirow[t]{2}{*}{ Hardness } & $r$ & - & - & - & - & - & - & - & - & - & - & 1.000 \\
\hline & $P$ value & - & - & - & - & - & - & - & - & - & - & - \\
\hline
\end{tabular}

$\mathrm{T}_{4}$, thyroxine; $\mathrm{T}_{3}$, triiodothyronine; $\mathrm{TSH}$, thyroid-stimulating hormone; Tg, thyroglobulin; UIC, urinary iodine concentration; USCN, urinary thiocyanate. ${ }^{*}$ Correlation is significant at the 0.05 level (two-tailed).

tSpearman's correlation coefficient.

¥Significance on two-tailed test.

Table 2 shows the correlation between various clinical indicators of thyroid function in schoolchildren and the concentration of water chemicals in Port Sudan. It indicates that thyroid hormones $\left(\mathrm{T}_{3}\right.$ and $\left.\mathrm{T}_{4}\right)$ were poorly correlated with the concentration of water chemicals. TSH was significantly correlated with $\mathrm{F}^{-}$concentration $(r=0 \cdot 506$, $P=0 \cdot 004)$ and inversely correlated with $\mathrm{Ca}^{2+}$ concentration $(r=-0.506, P=0.004)$ and hardness $(r=-0.506$, $P=0 \cdot 004)$. There was also a significant inverse correlation between UIC and the concentration of $\mathrm{Cl}^{-}(r=-0 \cdot 405$, $P=0 \cdot 024)$ and $\mathrm{Mg}^{2+}(r=-0 \cdot 405, P=0 \cdot 024)$. Some of the water samples collected from Port Sudan contained excessive concentrations of $\mathrm{Cl}^{-}, \mathrm{Ca}^{2+}, \mathrm{Mg}^{2+}$ and water hardness $(369 \cdot 2,116 \cdot 48,60 \cdot 21$ and $539 \cdot 0 \mathrm{mg} / \mathrm{l}$, respectively) exceeding the maximum levels recommended by the $\mathrm{WHO}^{(29,30)}$.

\section{Discussion}

The schoolchildren selected from the coastal city of Port Sudan had an excessive iodine intake according to the criteria of the $\mathrm{WHO}^{(31)}$ based on UIC. A couple of factors might have contributed to this excessiveness. Merely being coastal might be associated with the consumption of high amounts of seafood rich in iodine or the inhalation of iodine from the iodine-rich sea environment. Indeed, up to $20 \mu \mathrm{g}$ of iodine was estimated to be inhaled from such an environment by an adult person every day $^{(32)}$. In addition, the distribution by UNICEF and WHO of food fortified with iodine to the poorest schoolchildren in the Red Sea State was reported by Hussein et al. ${ }^{(33)}$. This could be another factor leading to the excessive urinary iodine excretion among children in this city. A median UIC of $55.5 \mu \mathrm{g} / \mathrm{dl}$ was reported in Hussein et al.'s study ${ }^{(33)}$.

It is noteworthy that studies done in the 1980s reported relatively low urinary iodine excretion with lower goitre rates in this city as compared with the recent studies ${ }^{(22,33)}$. The reason for the high goitre prevalence despite excess iodine intake in the present study needs further evaluation. One possible contributing factor may be the iodine intake as reported previously ${ }^{(33)}$. Dietary goitrogens are unlikely to be involved in the development of goitre in this population since the urinary excretion of thiocyanate was comparatively low.

The high mineral content of the water samples analysed in the present study seems to have no contribution in the goitre aetiology. Indeed, the high concentrations of $\mathrm{Cl}^{-}, \mathrm{Ca}^{2+}, \mathrm{Mg}^{2+}$ and $\mathrm{F}^{-}$, as well as water hardness, were not correlated with serum levels of thyroid hormones $\mathrm{T}_{3}$ and $\mathrm{T}_{4}$ in the present children. With the exception of $\mathrm{F}^{-}$, all of these chemicals were inversely correlated with the level of serum TSH. This can exclude water chemicals from the list of goitrogens which may interfere with the thyroid function or goitre aetiology in Port Sudan city. The results of the present study thus disagree with previous findings ${ }^{(11-14)}$ in which increased water chemicals interfered with thyroid hormone production.

It is well known that excessive iodine intake can block thyroid hormone synthesis and release $\mathrm{s}^{(3,35)}$. This could 
be clearly detected by the reduced serum $\mathrm{T}_{4}$ and $\mathrm{T}_{3}$ levels and elevated serum TSH level of the children in this coastal city compared with their peers in the other cities where iodine intake is insufficient. Furthermore, the present findings indicate that excessive intake of iodine may have adverse health impacts on the thyroid gland greater than those induced by the iodine deficiency in the populations of the non-coastal cities. This may indicate also that iodine deficiency can be well tolerated and overcome by the thyroid gland. Normal thyroid hormone concentrations were detected in children living in iodine-deficient Sudanese cities where the median UIC was only $2 \cdot 7 \mu \mathrm{g} / \mathrm{dl}^{(24)}$. Our findings are in line with what was revealed in a similar study $^{(36)}$, i.e. that the thyroid gland can compensate by a number of mechanisms to maintain sufficient thyroid hormone production when iodine supply is limited. The elevated Tg values in Port Sudan compared with the other cities is another indicator for thyroid abnormalities. In a similar cross-sectional study, a negative correlation between $\mathrm{Tg}$ and UIC and a positive correlation between $\mathrm{Tg}$, thyroid volume and TSH were reported ${ }^{(37)}$. The association between excess UIC and high prevalence of goitre could be extracted from the global scorecard for iodine-deficiency disorders ${ }^{(19)}$; the prevalence of goitre in some African countries surrounding Sudan was 63\% in Chad, 36.7\% in Eritrea and $36 \cdot 3 \%$ in Tunisia, while their corresponding UIC were $21 \cdot 3,16 \cdot 8$ and $16 \cdot 4 \mu \mathrm{g} / \mathrm{dl}$, respectively. In another endemic goitre study, the association of increased thyroid volume with UIC was detected only among children with UIC greater than $50 \mathrm{~g} / \mathrm{dl}^{(38)}$. Another explanation may arise from the hypothesis that a number of pupils have recently moved with their parents from iodine-deficient areas to the iodine-rich city of Port Sudan and developed iodine-induced hypothyroidism. This hypothesis is in line with previous reports ${ }^{(4,36)}$ that consumption of a high amount of iodine by a population who is iodine deficient may induce hypothyroidism. It might be of interest to note that excessive iodine intake has been shown to promote the development of autoimmune thyroid disease ${ }^{(3)}$ which might cause goitre and/or impair thyroid function ${ }^{(2)}$.

\section{Conclusions}

Excessive iodine intake is likely a factor in the aetiology of endemic goitre and reduced thyroid activity among schoolchildren in the coastal city of Port Sudan. High mineral content of drinking water and thiocyanate from food consumption were found to have no direct association with thyroid function or size. Measures should be taken to reduce the iodine intake of people living in this city.

\section{Acknowledgements}

Sources of funding: This work was funded by the SAEC. Conflicts of interest: There are no conflicts of interest.
Authors' contributions: The work was performed by A.M.M.H.M. and supervised by A.M.S. and A.A.E., who were actively involved in the design and follow-up. Acknowledgements: The authors acknowledge the health and education authorities in the nine states for giving them permission to collect the samples and for help during their stay in these states. The authors also extend thanks to the staff of the SAEC and the Groundwater \& Wadis Directorate for sample analysis.

\section{References}

1. Zimmermann MB (2009) Iodine deficiency. Endocr Rev 30, 376-408.

2. Markou K, Georgopoulos N, Kyriazopoulou V et al. (2001) Iodine-induced hypothyroidism. Thyroid 11, 501-510.

3. Laurberg P, Bulow Pedersen I, Knudsen N et al. (2001) Environmental iodine intake affects the type of nonmalignant thyroid disease. Thyroid 11, 457-469.

4. Pedersen IB, Laurberg P, Knudsen N et al. (2007) An increased incidence of overt hypothyroidism after iodine fortification of salt in Denmark: a prospective population study. J Clin Endocrinol Metab 92, 3122-3127.

5. Suzuki H, Higuchi T, Sawa K et al. (1965) Endemic coast goitre Hokkaido, Japan. Acta Endocrinol (Copenh) 50, $161-176$

6. Li M, Liu DR, Qu CY et al. (1987) Endemic goitre in Central China caused by excessive iodine intake. Lancet $\mathbf{1}$, 257-259.

7. Seal AJ, Creeke Pl, Gnat D et al. (2006) Excess dietary iodine intake in long-term African refugees. Public Health Nutr 9, 35-39.

8. Sigurdsson G \& Franzson L (1988) Urine excretion of iodine in an Icelandic population. Icelandic Med J $\mathbf{7 4 ,}$ 179-181.

9. Bayoumi RA, Taha SM \& Saha N (1988) Study of possible genetic predisposition to endemic goitre among the Fur and Baggara Tribes of the Sudan. Hum Hered 38, 8-11.

10. Boas M, Feldt-Rasmussen U, Skakkebæk NE et al. (2006) Environmental chemicals and thyroid function. Eur $J$ Endocrinol 154, 599-611.

11. Konova M, Keov EB \& Levkut M (1999) The effects of chlorine intake on some morphometric parameters of the thyroid gland in lambs. Acta Vet 68, 191-195.

12. Bercz JP, Jones LL, Garner L et al. (1982) Subchronic toxicity of chlorine dioxide and related compounds in drinking water in the nonhuman primate. Environ Health Perspect 46, 47-55.

13. Taylor S (1954) Calcium as goitrogenic. J Clin Endocrinol Metab 14, 1412.

14. Steyn DG (1955) Endemic Goitre in the Union of South Africa and Some Neighbouring Territories. Pretoria: Union of South Africa, Department of Nutrition.

15. Jooste PL (1999) Endemic goitre in the absence of iodine deficiency in schoolchildren of the Northern Cape Province of South Africa. Eur J Clin Nutr 53, 8-12.

16. Wilson D (1941) Fluorine in the aetiology of endemic goitre. Lancet 15, 212-213.

17. Day TK \& Powell-Jackson PR (1972) Fluoride, water hardness, and endemic goitre. Lancet 1, 1135-1138.

18. Anonymous (2010) Global IDD Scorecard 2010. IDD Newsletter 35, issue 1, 14-16.

19. Eltom M (1984) Endemic goitre in Sudan. PhD Thesis, Uppsala University.

20. Osman AK \& Fatah AA (1981) Factors other than iodine deficiency contributing to the endemicity of goitre in Darfur Province (Sudan). J Hum Nutr 35, 302-309. 
21. Elnour A, Hambraeus L, Eltom M et al. (2000) Endemic goitre with iodine sufficiency: a possible role for the consumption of pearl millet in the etiology of endemic goitre. Am J Clin Nutr 71, 59-66.

22. Medani AMMH, Elnour AA \& Saeed AM (2011) Endemic goitre in the Sudan despite long-standing programmes for the control of iodine deficiency disorders. Bull World Health Organ 89, 121-126.

23. Kevin M, Robin H, Jonathan G et al. (1995) Monitoring Universal Salt Iodization Programs (WHO/ICCIDD/UNICEF/MI Manual), pp. 58-71. Geneva: WHO, UNICEF and International Council for the Control of Iodine Deficiency Disorders.

24. World Health Organization, UNICEF \& International Council for Control of Iodine Deficiency Disorders (1994) Indicators for Assessing Iodine Deficiency Disorders and their Control Through Salt Iodization (WHO/NUT/94.6). Geneva: WHO.

25. Pino S, Fang SL \& Braverman LE (1996) Ammonium persulfate: a safe alternative oxidizing reagent for measuring urinary iodine. Clin Chem 42, 239-243.

26. Aldridge WN (1945) The estimation of micro quantities of cyanide and thiocyanate. Analyst (Lond) 70, 474-475.

27. Michajlovskij N \& Langer P (1958) Studies on relations between thiocyanate formation and goitrogenic properties of foods. I. Preformed thiocyanate content of some foods. Hoppe Seylers Z Physiol Chem 312, 26-30.

28. Clesceri LS, Greenberg AE \& Eaton AD (editors) (2000) Standard Methods for the Examination of Water and Wastewater, 20th ed. Washington, DC: American Public Health Association, American Water Works Association and Water Environment Federation.

29. World Health Organization (1971) International Standards for Drinking Water, 3rd ed. Geneva: WHO.
30. World Health Organization (1984) Guidelines for DrinkingWater Quality, vol. II, Geneva: WHO.

31. World Health Organization, UNICEF \& International Council for Control of Iodine Deficiency Disorders (2001) Assessment of Iodine Deficiency Disorders and Monitoring their Elimination. A Guide for Programme Managers (WHO/NHD/01.1). Geneva: WHO.

32. Koutras DA, Josip M \& Vought R (1980) The ecology of iodine. In Endemic Goitre and Endemic Cretinism: Iodine Nutrition in Health and Disease, pp. 185-195 [JB Stanbury and BS Hetzel, editors]. New York: Wiley.

33. Hussein SI, Crawford MA \& Jooste PL (2007) Population living in the Red Sea State of Sudan may need urgent intervention to correct the excess dietary iodine intake. Nutr Rev 18, 333-341.

34. Safran M, Paul TL, Roti E et al. (1987) Environmental factors affecting autoimmune thyroid disease. Endocrinol Metab Clin North Am 16, 327-342.

35. Pisarev MA \& Gartner R (2000) Autoregulatory actions of iodine. In The Thyroid, 8th ed., pp. 85-90 [LE Braverman and RD Utiger, editors]. Philadelphia, PA: Lippincott.

36. Pedersen IL, Nils K, Torben J et al. (2002) Large differences in incidences of overt hyper- and hypothyroidism associated with a small difference in iodine intake: a prospective comparative register-based population survey. J Clin Endcrinol Metab 87, 4462-4469.

37. Knudsen N, Bülow I, Jorgenson T et al. (2001) Serum thyroglobulin a sensitive marker of thyroid abnormalities and iodine deficiency in epidemiologic studies. $J$ Clin Endocrinol Metab 86, 3599-3603.

38. Zimmermann MB, Ito Y, Hess SY et al. (2005) High thyroid volume in children with excess dietary iodine intakes. $\mathrm{Am} \mathrm{J}$ Clin Nutr 81, 840-844. 